\title{
Hormonal regulation of preovulatory follicle maturation in the rat
}

\author{
S. G. Hillier*, A. J. Zeleznik †; R. A. Knazek and G. T. Ross \\ National Institutes of Health, Bethesda, Maryland 20014, U.S.A.
}

\begin{abstract}
Summary. Oestrogen-priming of the hypophysectomized immature female rat promotes preantral follicle development in the absence of endogenous gonadotrophins and such an animal is useful for study of the intraovarian glycoprotein-steroidal hormone interactions which underlie morphological and functional development of the ovarian follicle. The present report identifies in vitro the functional characteristics (gonadotrophin binding and steroidogenesis) of granulosa cells harvested at different stages of follicular maturity following treatment with exogenous hormones in vivo. Preovulatory follicle maturation, induced by FSH, has been studied up until antrum formation and the acquisition by granulosa cells of the ability to respond directly to $\mathrm{LH}$ or hCG. Before the increases in available granulosa cell membrane $\mathrm{LH} / \mathrm{hCG}$ receptors associated with the formation of follicular antra, effects of hCG or other hormones with interstitial cell stimulating activity are mediated via interactions with cells outside the lamina basalis. In-vivo studies with oestrogen-primed hypophysectomized immature rats indicate that androgens secreted by $\mathrm{LH} / \mathrm{hCG}$-stimulated thecal and/or interstitial cells may act directly on the preantral follicle to promote atresia. However, in-vitro studies have shown a stimulatory effect of androgen on FSH-responsive progesterone secretion by granulosa cells isolated from preantral follicles. These effects, if shown to operate within the ovary during the normal cycle, need not be mutually exclusive because FSH stimulation of granulosa cells in vivo may be a major determinant of follicular responses to androgen. The increase in follicle size and antrum formation accompanying FSH treatment in vivo are associated with (i) increases in the steroidogenic potential of isolated granulosa cells; (ii) the induction of granulosa cell $\mathrm{LH} / \mathrm{hCG}$ receptors and of steroidogenic responsivity to $\mathrm{hCG}$; and (iii) stimulation of granulosa cell aromatase activity. These observations highlight the critical role of FSH in the organization of preovulatory follicular morphology and function.
\end{abstract}

\section{Introduction}

During successive oestrous cycles, in the ovary of the rat a few well advanced preantral follicles undergo the final stages of maturation, culminating in antrum formation and the ability to respond to the ovulatory surge of LH. Granulosa cell differentiation during this period is characterized by intracellular modifications leading to increased steroidogenesis and by an increase in the number of available cell membrane LH receptors. While FSH plays a major role in these changes, several studies attest to the importance of intraovarian oestrogens acting

* Present address: Department of Obstetrics and Gynaecology, University Hospital, Leiden, The Netherlands.

† Present address: Departments of Physiology and Obstetrics and Gynecology, Magee-Women's Hospital, University of Pittsburgh, Pittsburgh, Pennsylvania 15213, U.S.A. 
locally to regulate follicular responses to gonadotrophins (e.g. Pencharz, 1940; Williams, 1940; Smith \& Bradbury, 1963). Studies with hypophysectomized immature female rats given graded doses of diethylstilboestrol showed that oestrogen stimulated ovarian weight and that this response was the product of a reduction in follicular atresia and a concomitant stimulation of preantral follicle growth (Payne \& Hellbaum, 1955). Goldenberg, Vaitukaitis \& Ross (1972) showed a synergistic effect on ovarian weight when graded doses of FSH were administered following 2-4 days of diethylstilboestrol. In contrast to the predominance of large preantral follicles in ovaries of animals receiving diethylstilboestrol alone, numerous antral follicles were present following treatment with both hormones. The mechanism through which oestrogen exerted this effect entailed increased ovarian uptake of labelled FSH (Goldenberg et al., 1972). Granulosa cells contain cytosolic and nuclear receptors for oestrogen (Richards \& Midgley, 1976) and are thought to be the exclusive site of FSH receptors in the ovary (Zeleznik, Midgley \& Reichert, 1974). An analysis of FSH receptor numbers per ovary and per granulosa cell from ovaries removed before and after treatment of hypophysectomized immature rats with graded doses of oestrogen revealed that oestrogens acted to increase FSH receptor activity principally by stimulation of granulosa cell proliferation (Louvet \& Vaitukaitis, 1976).

Between 4 and 6 days after hypophysectomy and initiating treatment with oestrogen (at 21 days of age) the ovaries of oestrogen-primed immature rats contain a relatively homogeneous population of solid preantral follicles with multiple granulosa cell layers (Pl. 1, Fig. 1). Most of these follicles are greater than $200 \mu \mathrm{m}$ in diameter (Louvet, Harman, Schreiber \& Ross, 1975b) but rarely exceed $400 \mu \mathrm{m}$ (Erickson \& Hsueh, 1978). In the intact cyclic adult the Graafian follicles that will ovulate during the next oestrus develop from the preantral follicles which fall within this size range at the beginning of a normal cycle (Lane \& Davis, 1939; Boling, Blandau, Soderwell \& Young, 1941; Pederson, 1970). Moreover, there is evidence that between the onset of oestrus and ovulation it is the follicles within this category $(250-349 \mu \mathrm{m})$ that are increasingly involved in the processes of atresia and degeneration (Mandl \& Zuckerman, 1952). In view of these considerations, a systematic appraisal of the gonadotrophic and steroidal hormone interactions associated with the processes of antrum formation and atresia in the follicles of oestrogen-primed ovaries of hypophysectomized rats may provide information relevant to the events which take place during preovulatory follicle maturation. Similar studies with intact cyclic animals suffer from the constraints imposed by steroid hormones feeding back on pituitary gonadotrophin secretion.

In the present report, we summarize and discuss major hormonal interactions which underlie altered follicular morphology and granulosa cell function in the ovaries of oestrogen-primed hypophysectomized immature rats.

\section{Studies pertaining to the role of $\mathrm{LH}$ in preovulatory follicle maturation}

Human chorionic gonadotrophin (hCG) has been used instead of $\mathrm{LH}$ in these studies because it binds to the same receptors as $\mathrm{LH}$, is available in a highly purified form and is more stable than LH after radioiodination. All the experiments refer to rats hypophysectomized at 21 days of age.

In preantral follicles, LH binds to and acts specifically on thecal and interstitial cells (Zeleznik et al., 1974), but does not bind to the granulosa cells (Channing \& Kammerman, 1973; Lee, 1976; Stouffer, Tyrey \& Schomberg, 1976; Hillier, Zeleznik \& Ross, 1978).

Treatment of hypophysectomized immature females with oestrogen significantly increases the weight of the ovaries, but administration of hCG to such animals inhibits the oestrogen-stimulated ovarian weight gain (Louvet, Harman \& Ross, 1975a; Louvet et al., 1975b): maximal inhibition is induced by a dose of $0.3 \mathrm{mi}$.u. per animal (Text-fig. 1). Since the effect was specific for hCG and human LH and could not be reproduced by treatment with an FSH preparation devoid of significant interstitial cell-stimulating activity, it was suggested that gonadotrophic stimulation of ovarian thecal and/or interstitial tissue mediated this response. 
Histological studies revealed that the reduction in ovarian weight induced by low doses of hCG was accompanied by interstitial cell stimulation, a reduction in follicle size, and a marked increase in the incidence of follicular atresia. Since co-administration of specific chemical or biological antagonists of androgen action reversed the last two effects of hCG, it was suggested that androgens secreted by interstitial and/or thecal cells in response to hCG act locally to inhibit the effect of oestrogen on follicle growth (Louvet et al., 1975b). More recent experiments demonstrated the anti-oestrogenic action of testosterone directly, showing both time- and dose-dependent reductions in oestrogen-stimulated ovarian weight (Text-fig. 1) and promotion of follicular atresia (Hillier \& Ross, 1979).

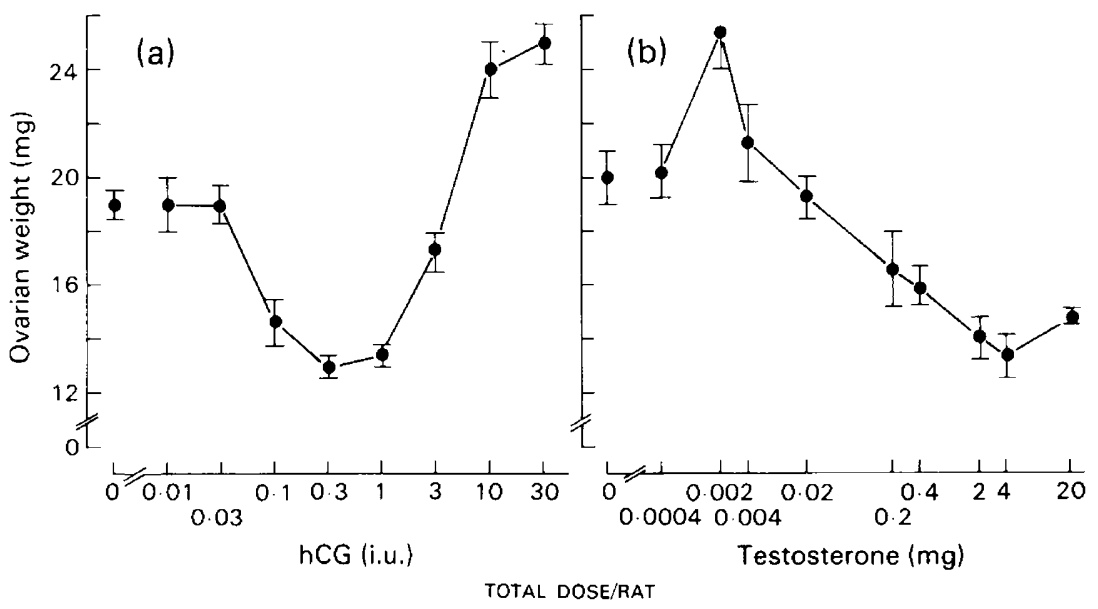

Text-fig. 1. Effects of (a) hCG and (b) testosterone on ovarian weight in oestrogen-primed hypophysectomized rats. Mean paired ovarian weight ( \pm 1 s.e.m.) at 27 days of age is plotted as a function of the total dose of hormone/animal, administered as twice daily s.c. injections during the 4 days before death. Hypophysectomy and s.c. placement of a $1 \mathrm{~cm}$ Silastic capsule containing diethylstilboestrol was performed at 21 days of age. Data from Louvet et al. (1975b) and Hillier \& Ross (1979).

Consistent with the aforementioned finding that granulosa cells from oestrogen-primed hypophysectomized rats had a limited ability to bind ${ }^{125} \mathrm{I}$-labelled hCG, the addition of hCG $(10-1000 \mathrm{mi} . \mathrm{u} . / \mathrm{ml})$ to granulosa cell culture medium had no effect on progesterone secretion by these cells (Hillier, Knazek \& Ross, 1978). On the other hand, the addition of testosterone or $5 \alpha$-dihydrotestosterone (but not oestradiol or diethylstilboestrol) to the culture medium resulted in dose- and time-dependent increases in progesterone production (Lucky, Schreiber, Hillier, Schulman \& Ross, 1977). This effect (Text-fig. 2) was inhibited in the presence of the non-steroidal antiandrogen, SCH-16423 (Hillier et al., 1977), a derivative of flutamide which inhibits ovarian nuclear uptake of tritiated testosterone in vivo (Zeleznik, Hillier \& Ross, 1979), presumably by inhibiting the nuclear translocation of cytoplasmic testosterone-receptor complexes within granulosa cells (Schreiber \& Ross, 1976). Androgen has also been shown to stimulate progestagen production by cultured granulosa cells from mature antral follicles of cyclic rats and pigs (Nimrod \& Lindner, 1976; Schomberg, Stouffer \& Tyrey, 1976). The ability to secrete progestagens and respond in this fashion to androgens in vitro may therefore represent a biochemical characteristic of the preantral granulosa cell which is retained throughout preovulatory follicle maturation in vivo. 


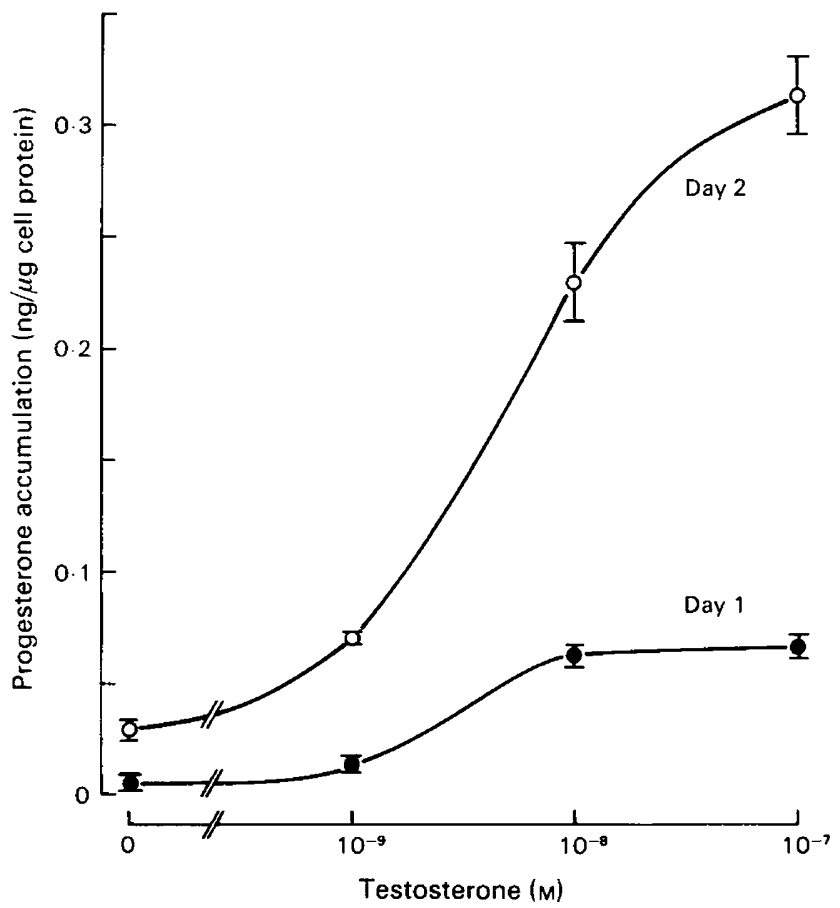

Text-fig. 2. Dose- and time-dependency of testosterone-stimulated progesterone production by granulosa cells from the preantral follicles of oestrogen-primed hypophysectomized rats. Granulosa cells were taken from 27-day-old animals which were hypophysectomized and received (s.c.) a $1 \mathrm{~cm}$ Silastic implant containing diethylstilboestrol at 21 days of age. Each value represents the mean \pm 1 s.e.m. of determinations on 4 replicate cultures. Data from Hillier et al. (1977).

The potential interactions between androgens and FSH during the stimulation of steroidogenesis are of importance. In contrast to our own findings, Armstrong \& Dorrington (1976) reported that granulosa cells isolated from preantral follicles in oestrogen-primed hypophysectomized rats produced "minimal" amounts of progesterone regardless of whether androgen was present in the culture medium. However, incubations in the presence of FSH stimulated progesterone production and this effect was augmented when testosterone or $5 \alpha$-dihydrotestosterone was included with FSH in the culture medium. We have re-examined this interaction and the results (Text-fig. 3) confirm that testosterone and FSH have independent stimulatory effects on progesterone production during a $48 \mathrm{~h}$ period of culture (approximately 5 -fold and 16-fold, respectively, in the experiment shown), whereas co-incubations in the presence of both hormones elicit a synergistic response (94-fold relative to controls). In addition we found that the stimulatory and synergistic effects of testosterone were inhibited in the presence of the specific antiandrogen, $\mathrm{SCH}-16423$, thereby emphasizing the specificity of the response to testosterone. These data suggest that this highly specific response to androgen may be important because of the augmentation of steroidogenesis induced by FSH rather than the induction of steroidogenesis per se.

The foregoing observations prompt the following speculations. The degree to which granulosa cells in preantral follicles have been or are being exposed to FSH may be a major determinant of the follicular response to androgens of thecal and/or interstitial cell origin. Inadequate exposure may encourage an atretic response to androgen while appropriate stimulation with FSH may facilitate enhanced sensitivity of androgen-responsive steroido- 


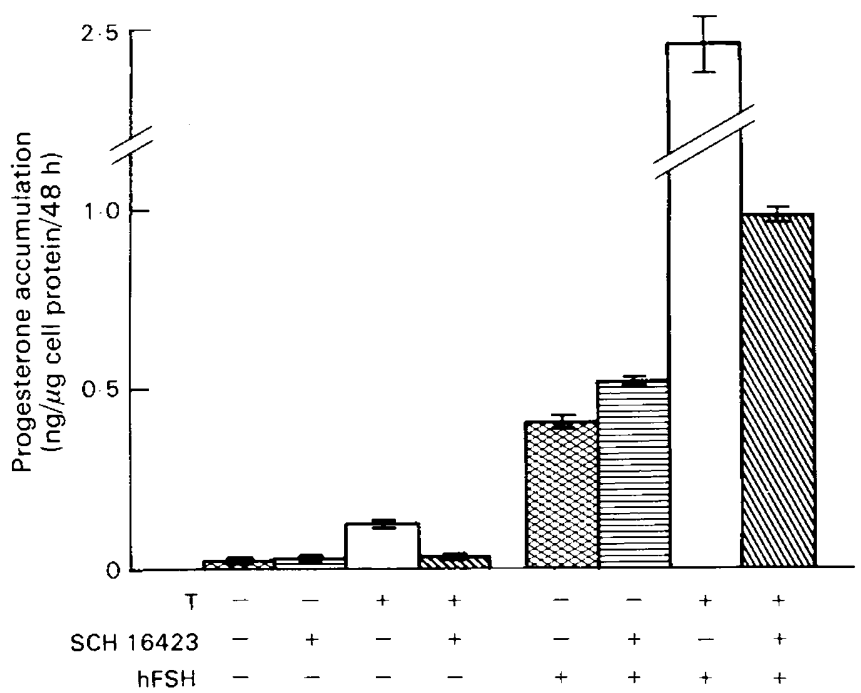

Text-fig. 3. Interaction between testosterone- and FSH-responsive progesterone secretion by granulosa cells isolated from the ovaries of 27-day-old oestrogen-primed hypophysectomized rats which were hypophysectomized and received (s.c.) a $1 \mathrm{~cm}$ Silastic capsule containing diethylstilboestrol at 21 days of age. The additions to the medium were nothing or various combinations of $10^{-7}$ M-testosterone (T), $100 \mathrm{ng} \mathrm{hFSH} \mathrm{(LER-8/116)/ml} \mathrm{and} 10^{-5} \mathrm{M}$ SCH-16423 ( $\alpha$ - $\alpha$ - $\alpha$-trifluoro-2-methyl-4'-nitro-m-lactotoluidide). Each value represents the mean \pm 1 s.e.m. of determinations on 4 replicate cultures. See Hillier et al. (1977) for methods.

genesis. Concomitant increases in the activity of granulosa cell aromatase enzyme(s) (see later) would also serve to increase the metabolism of aromatizable androgens to oestrogens, and thereby protect the follicle from the atretic effect of androgen. Although recent studies in vitro with isolated and recombined thecal and granulosa cells from preovulatory follicles suggest that an interaction between follicular granulosa cells and theca may be operational during FSH-stimulated progesterone synthesis (Makris \& Ryan, 1977), definitive evidence for either the atretic action or the steroidogenic action of androgen constituting a physiologically operational mechanism during normal cyclic follicle maturation is lacking.

\section{Studies pertaining to the role of FSH in preovulatory follicle maturation}

In the rat ovary FSH receptors are located exclusively on granulosa cells (Zeleznik et al., 1974). The importance of local effects of ovarian oestrogens to follicular responses elicited by FSH was indicated earlier (see above). FSH plays a central role in the induction of granulosa cell steroidogenesis and the increased number of available $\mathrm{LH}$ receptors which characterize the advanced stages of granulosa cell differentiation during preovulatory follicle maturation in the cyclic adult. Classical morphological correlates of FSH stimulation during this period are increased follicle size and the development of follicular antra: each of these effects have been observed after treatment of oestrogen-primed hypophysectomized rats with exogenous FSH (Pl. 1, Fig. 2).

Although molecular mechanisms underlying antrum formation remain obscure (Zachariae, 1959) studies with oestrogen-primed hypophysectomized rats have revealed a dose-dependent stimulation of ${ }^{35} \mathrm{SO}_{4}$ incorporation into ovarian proteoglycans by $\mathrm{FSH}$ in vivo (Mueller et al., 1978). Isolated granulosa cells in tissue culture were also able to secrete proteoglycans and to respond directly to exogenous $\mathrm{FSH}$ with an increase in ${ }^{35} \mathrm{SO}_{4}$ incorporation. 
Gonadotrophin-induced steroidogenesis in follicular cells is mediated by increases in the intracellular concentration of $3^{\prime}, 5^{\prime}$-cAMP which is thought to initiate a complex sequence of subcellular biochemical events which culminate in the induction or activation of one or more of the rate-limiting enzymic steps in steroidogenesis (Kolena \& Channing, 1972; Marsh, 1976). Granulosa cells obtained from the preantral follicles of oestrogen-primed hypophysectomized rats contain a membrane-associated FSH-sensitive adenylate cyclase system and progesterone secretion by these cells is stimulated by FSH in vitro (Text-fig. 4; Hillier et al., 1978).

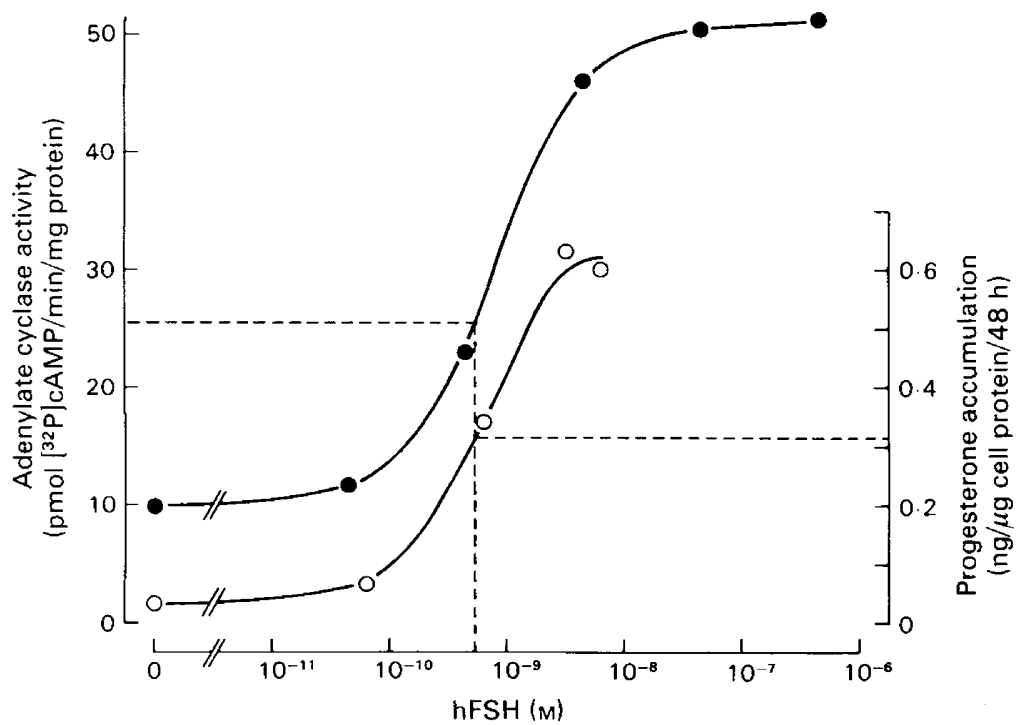

Text-fig. 4. Relationship between membrane-associated FSH-sensitive adenylate cyclase activity in $(\mathcal{)}$ and progesterone secretion by $(O)$ granulosa cells isolated from the preantral follicles of 27-day-old oestrogen-primed hypophysectomized rats. The animals were hypophysectomized and received (s.c.) a $1 \mathrm{~cm}$ Silastic capsule containing diethylstilboestrol at 21 days of age. Adenylate cyclase activities in a crude membrane fraction were determined by the procedure of Salomon, Londos \& Rodbell (1974) but with a $10 \mathrm{~min}$ reaction sequence. Progesterone production represents the accumulation of immunoreactive progesterone in culture medium during a $48 \mathrm{~h}$ incubation of cell suspensions. The responses (mean of triplicate incubations) are shown as a function of hFSH concentration. The hFSH preparation used (LER-8/116) contained approximately 900 i.u. FSH and 6 i.u. LH/mg. Calculation of the molar concentration of hFSH was made assuming the biological activity of 'pure' FSH to be 4000 i.u./mg and the mol. wt to be 35000 . The half-maximal value of both responses (indicated by the broken lines) was elicited by the same concentration of FSH $\left(5.3 \times 10^{-10} \mathrm{M}\right.$ 'pure' hFSH; i.e. $82.4 \mathrm{ng}$ LER 8/116 ml). Data from Hillier et al. (1978).

Direct evidence for the importance of FSH in the induction of granulosa cell steroidogenesis during the course of antrum formation was adduced from studies of granulosa cells collected after treatment with exogenous FSH (Table 1). In these experiments suspensions of granulosa cells isolated from control animals (injected with saline) did not produce measurable amounts of progesterone $(<0.8 \mathrm{pg} / \mu \mathrm{g}$ cell protein) during 90 and 240 min incubations, even when $\mathrm{hFSH}$ or dibutyryl cAMP were added to the culture medium at concentrations known to stimulate steroidogenesis during longer incubations. On the other hand, treatment with FSH for $24 \mathrm{~h}$ before removal of the granulosa cells (sufficient to stimulate early antrum formation as shown in Pl. 1, Fig. 2) led to readily detectable basal secretion of progesterone (no additions to culture medium) which was stimulated 3.4- and 1.6-fold after $240 \mathrm{~min}$ in the presence of FSH and dibutyryl cAMP, respectively. Short-term incubations of whole follicles gave similar results 
Table 1. Effect of FSH treatment in vivo on early basal, FSH- and dibutyryl cAMPresponsive progesterone production (mean \pm s.e.m. for 3 determinations) by isolated rat granulosa cells

\begin{tabular}{lccc}
\hline & & \multicolumn{2}{c}{ Progesterone production $(\mathrm{pg} / \mu \mathrm{g}$ cell protein) } \\
\cline { 3 - 4 } Treatment in vivo & Addition to culture medium & $1.5 \mathrm{~h}$ & $4 \mathrm{~h}$ \\
\hline Saline & None & ND & ND \\
& hFSH & ND & ND \\
oFSH $(24 \mathrm{~h})$ & dbcAMP & ND & ND \\
& None & $48.7 \pm 3.6$ & $59.3 \pm 6.4$ \\
& hFSH & $67.3 \pm 16.1$ & $201.9 \pm 20.0$ \\
& dbcAMP & $42.7 \pm 4.5$ & $94.6 \pm 12.5$ \\
\hline
\end{tabular}

Granulosa cell suspensions were prepared from the ovaries of 27-day-old oestrogen-primed hypophysectomized immature rats receiving s.c. injections of saline or $100 \mu \mathrm{g}$ oFSH in saline at 24 and $12 \mathrm{~h}$ before death. The accumulation of immunoreactive progesterone in culture medium was determined following 1.5 and $4 \mathrm{~h}$ of incubation in medium containing no additions and containing $500 \mathrm{ng}$ hFSH (LER-8/116)/ml or $1 \mathrm{mm-dibutyryl} \mathrm{cAMP} \mathrm{(dbcAMP).} \mathrm{See} \mathrm{Hillier}$ et al. (1978) for Methods. ND $=$ not detectable $(<0.8 \mathrm{pg} / \mu \mathrm{g}$ cell protein $)$.

(Zeleznik, Keyes, Menon, Midgley \& Reichert, 1977). FSH-sensitive adenylate cyclase activities in granulosa cell membranes from control and FSH-treated animals are alike (Hillier et al., 1978). Thus the action of FSH on steroidogenesis is mediated by the activation or sensitization of a biochemical $\operatorname{step}(\mathrm{s})$ located distally to the primary membrane effector interaction and the locus of cAMP production (Hillier et al., 1978). Histochemical studies of steroidogenic enzymes in the ovaries of adult rats during the oestrous cycle suggest that $3 \beta$-hydroxysteroid dehydrogenase activity in the granulosa cells of maturing follicles increases as the cycle proceeds, becoming apparent in some of the larger growing follicles on the 2nd day of dioestrus and increasing markedly by pro-oestrus (Pupkin, Bratt, Weisz, Lloyd \& Balogh, 1966). Moreover, Zeleznik et al. (1974), also using histochemistry, reported that granulosa cell $3 \beta$-hydroxysteroid dehydrogenase activity and antrum formation was stimulated following the treatment of immature rats with FSH. Collectively, these observations imply that FSH may be responsible for the induction or activation of one or more of the major rate-limiting steroidogenic enzymes present in the granulosa cells of preovulatory follicles.

The increased steroidogenic capacity which granulosa cells acquire during preovulatory follicle maturation in the cyclic mammal is associated with an increased ability to bind ${ }^{125}$ I-labelled hCG (Channing \& Ledwitz-Rigby, 1975). Granulosa cells harvested from large preovulatory follicles undergo morphological 'luteinization' when placed into culture and basal levels of progestagen secretion are substantial. Progestagen secretion is further increased when LH or hCG are included in the culture medium (Channing, 1970).

The critical role of $\mathrm{FSH}$ in the induction of granulosa cell $\mathrm{LH} / \mathrm{hCG}$ receptors was illustrated by the studies of Zeleznik et al. (1974) showing that binding of ${ }^{125}$ I-labelled hCG to the granulosa cells of immature rat ovaries was markedly stimulated after treatment with rat FSH in vivo for 2 days. An examination of the relationship between FSH-induced $\mathrm{LH} / \mathrm{hCG}$ receptors and the steroidogenic capacity of granulosa cells of oestrogen-primed hypophysectomized rats showed that early antrum formation following treatment with FSH for $24 \mathrm{~h}$ was associated with marked increases in both steroidogenic potential and binding of ${ }^{125} \mathrm{I}$-labelled hCG in vitro (Hillier et al., 1978). The 9-fold increase in hCG binding induced by FSH treatment in vivo was shown to reflect the acquisition of functional $\mathrm{LH} / \mathrm{hCG}$ receptors since it was accompanied by the ability of isolated granulosa cells to respond to low concentrations of hCG with striking increases in progesterone production (Text-fig. 5).

Oestrogens are clearly important for the early stages of normal follicular development and

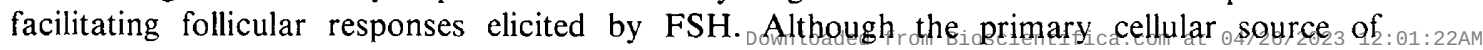




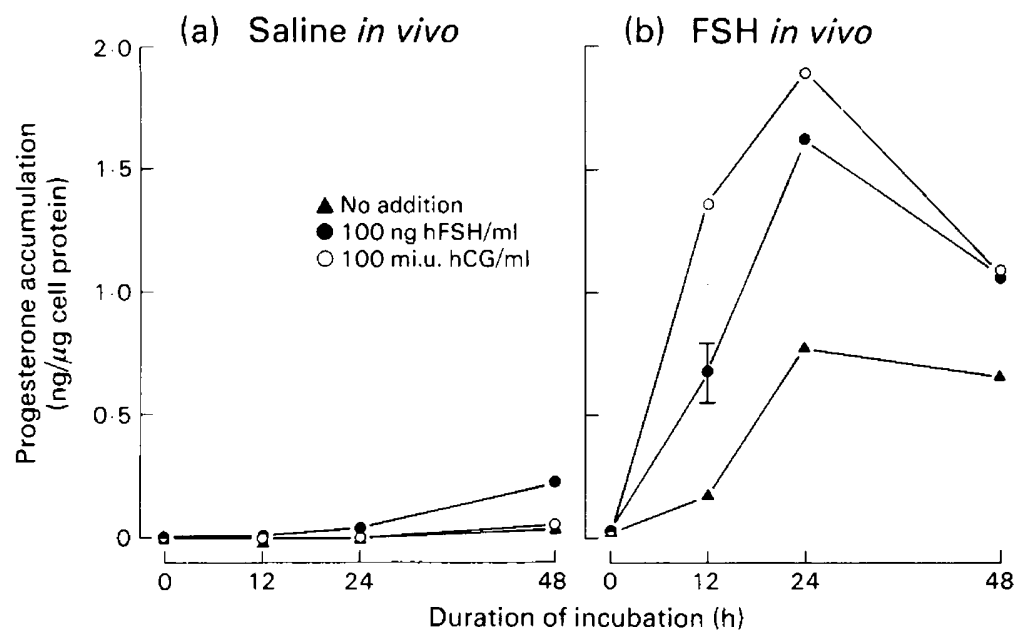

Text-fig. 5. Effect of FSH treatment in vivo on basal (A), FSH ( (O, CR-119)-responsive progesterone secretion in vitro by granulosa cells from the ovaries of 27-day-old oestrogen-primed hypophysectomized rats. Cell suspensions were prepared (approximately $10^{6} \mathrm{cells} / \mathrm{ml}$ ) from the ovaries of animals receiving s.c. injections of (a) saline $(9 \mathrm{~g} \mathrm{NaCl} / \mathrm{l})$ or (b) $100 \mu \mathrm{g}$ oFSH (LER-1698) in saline at 24 and $12 \mathrm{~h}$ before death. Values are the mean of triplicate incubations; with one exception the s.e.m. at each point was less than $10 \%$. Specific binding of ${ }^{125} \mathrm{I}$-labelled hCG, determined on freshly isolated cells (mean c.p.m. bound $x$ $10^{-3} / \mathrm{mg}$ cell protein \pm s.e.m.), was $0.45 \pm 0.4$ (saline in vivo) versus $3.9 \pm 1.0$ (24 h FSH in vivo). Data from Hillier et al. (1978).

oestrogen in the ovarian follicle has yet to be identified, preovulatory Graafian follicles are considered to be responsible for the large quantities of oestrogens secreted by the ovary into the peripheral circulation during oestrus (Baird \& Fraser, 1975; Makris \& Ryan, 1975). The classical experiments of Falck (1959) led to the conclusion that both theca and granulosa cells were required for ovarian oestrogen synthesis. Support for this hypothesis was provided by experiments in which intraovarian and peripheral blood levels of oestradiol were measured in hypophysectomized immature rats given androgens and FSH. Armstrong \& Papkoff (1976) showed that ovarian and peripheral blood oestradiol levels were elevated when graded doses of testosterone were followed with a fixed dose of FSH, but no such increments were found when $5 \alpha$-dihydrotestosterone (a non-aromatizable androgen) was given with the FSH. These results suggested that LH and hCG enhance ovarian synthesis of androgen which is aromatized to oestrogens. Experiments with tissue isolated from follicles of rats in pro-oestrus have confirmed that theca but not granulosa cells secrete aromatizable androgen and that this response is stimulated by LH in vitro (Fortune \& Armstrong, 1977). In addition, Dorrington, Moon \& Armstrong (1975) showed that FSH stimulated the secretion of oestradiol when granulosa cells from preantral follicles were incubated with testosterone, further suggesting that FSH stimulates aromatase activity in granulosa cells which can then convert androgens secreted by cells outside the lamina basalis into oestrogens.

Substantial increases in granulosa cell aromatase activity accompany preovulatory follicular development during the normal oestrous cycle: the highest activity is associated with mature Graafian follicles on the day of pro-oestrus (Hillier, van den Boogaard, Reichert \& van Hall, 1980). The relationship between FSH-induced follicular maturation and granulosa cell aromatase activity in oestrogen-primed hypophysectomized rats was established as follows. Granulosa cell suspensions were prepared from the ovaries of animals treated with saline (controls) or treated with FSH for 12 and $24 \mathrm{~h}_{\mathrm{D}}$ respectively before death. Replicate aliquots of 
PLATE 1
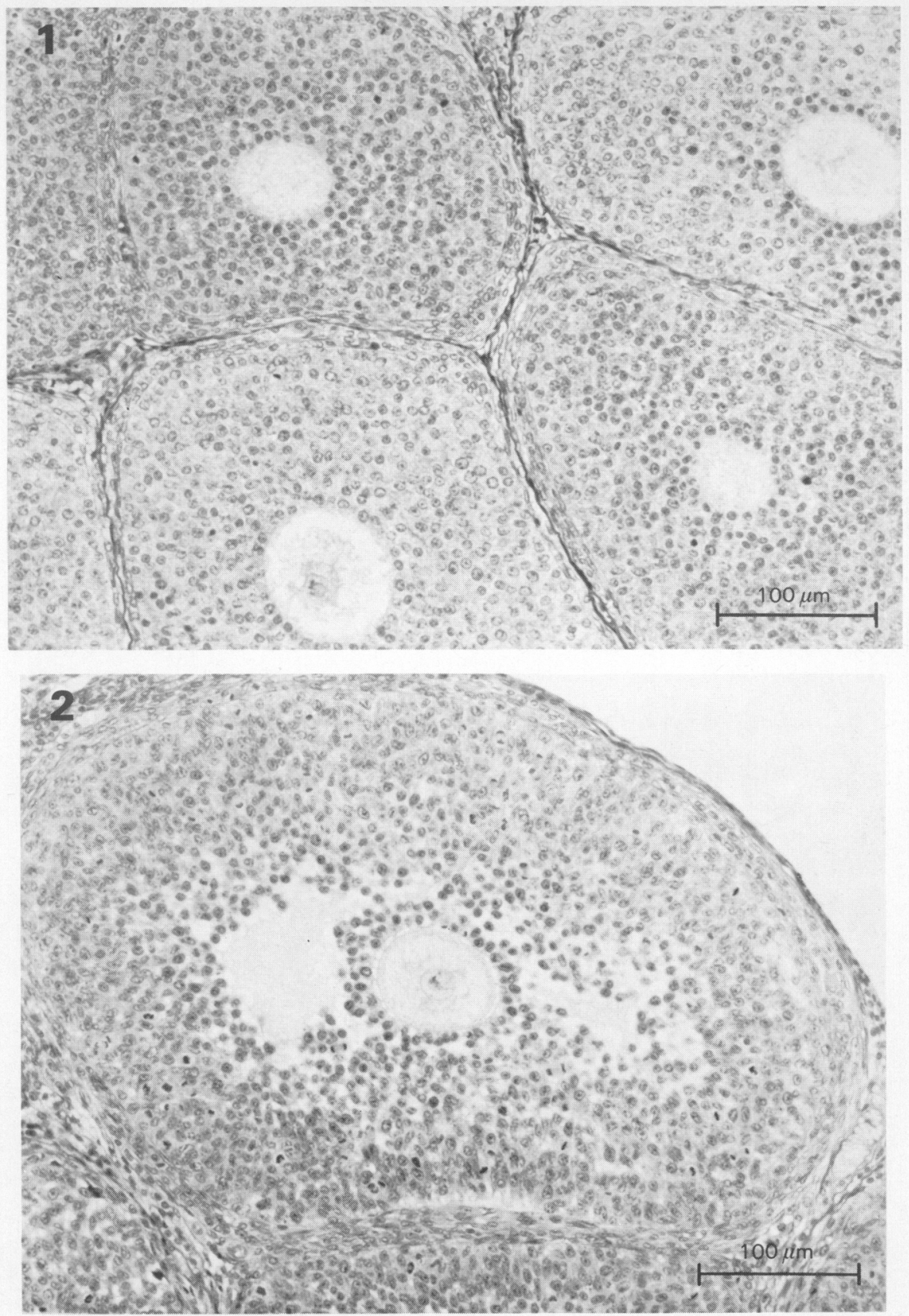

Fig. 1. Preantral follicular morphology in the ovary of a 27-day-old oestrogen-primed hypophysectomized immature rat. Hypophysectomy and subcutaneous implantation of a $1 \mathrm{~cm}$ Silastic capsule containing diethylstilboestrol was performed at 21 days of age. $\mathrm{H} \& \mathrm{E}, \times 220$.

Fig. 2. Early antrum formation following treatment as above plus a subcutaneous injection of $100 \mu \mathrm{g}$ ovine FSH (LER-1698) in saline administered 24 and $12 \mathrm{~h}$ before death at 27 days of age. $H \& E, \times 220$.

(Facing p. 226) 
each cell suspension were incubated for $48 \mathrm{~h}$ in culture medium containing no additions (controls), testosterone $\left(10^{-7} \mathrm{M}\right)$, human FSH $(100 \mathrm{ng} / \mathrm{ml})$ or a mixture of the two hormones. At the end of the incubation the concentration of immunoassayable oestradiol in spent culture medium was determined. The results (Text-fig. 6) show that early stages of antrum formation induced by $24 \mathrm{~h}$ of treatment with FSH (Pl. 1, Fig. 2) are associated with dramatic increases in the ability of isolated granulosa cells to aromatize testosterone. Under the experimental conditions employed, the concentration of testosterone, rather than FSH, added to the culture medium appeared to be the rate-limiting factor. However, the limited conversion of testosterone to oestradiol by cells from the control group (preantral follicles) was stimulated approximately 3 -fold in the presence of FSH in vitro. The intermediate period of FSH treatment in vivo (12 h) resulted in a 5-fold increase in oestradiol accumulation in the presence of testosterone alone (relative to cells isolated from saline-treated controls) and was further increased $1 \cdot 5$-fold when FSH was included in the culture medium. In similar experiments with oestrogen-primed hypophysectomized rats, Erickson \& Hsueh (1978) observed that after $48 \mathrm{~h}$ of FSH treatment (when follicular morphology was similar to that of preovulatory follicles of adult animals on the morning of pro-oestrus) granulosa cell aromatase activities had increased to levels which were comparable to those observed for granulosa cells isolated from the fully mature Graafian follicles of cyclic adults.

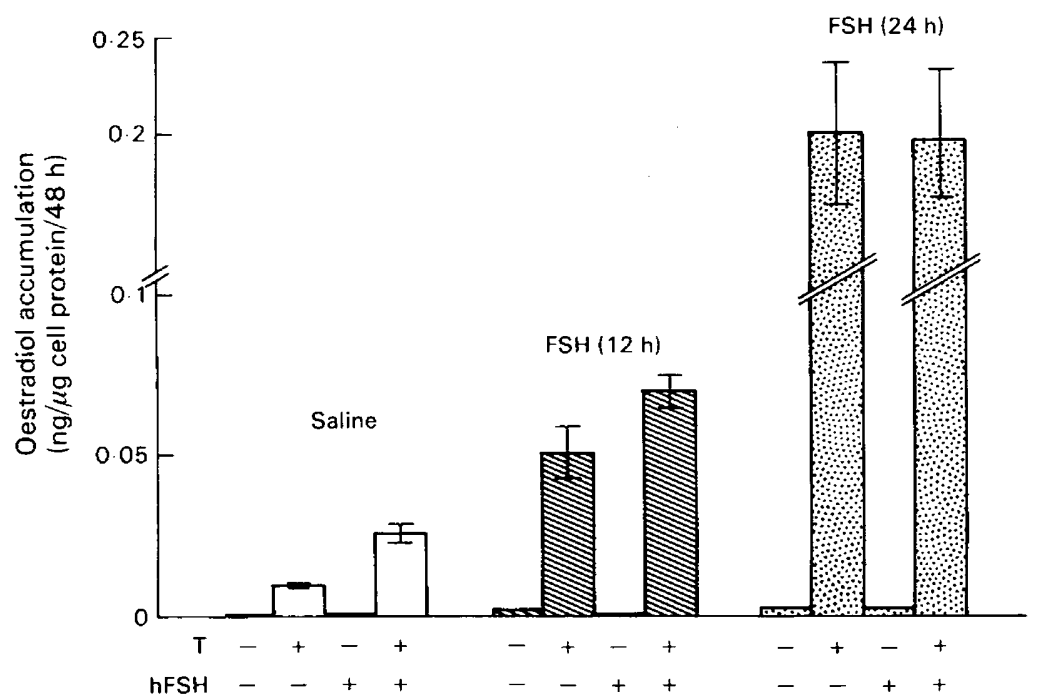

Text-fig. 6. Effect of FSH-treatment in vivo on isolated granulosa cell aromatase activity. Granulosa cell suspensions were prepared from the ovaries of 27-day-old oestrogen-primed hypophysectomized rats injected with saline $(9 \mathrm{~g} \mathrm{NaCl} / \mathrm{l})$ or $100 \mu \mathrm{g}$ oFSH (LER-1698) in saline at $12 \mathrm{~h}$ or 24 and $12 \mathrm{~h}$ before death. Additions to the culture medium were none or combinations of $10^{-7} \mathrm{M}$-testosterone (T) and $500 \mathrm{ng} \mathrm{hFSH} \mathrm{(LER-8/116)/ml.} \mathrm{Each} \mathrm{value} \mathrm{represents} \mathrm{the}$ mean \pm 1 s.e.m. of determinations on triplicate incubations. See Hillier et al. (1978) for methods.

The induction of granulosa cell aromatase activity would seem, therefore, to constitute a further functional correlate of FSH acting during the course of normal preovulatory follicle maturation.

We thank Dr Leo E. Reichert, Jr, Department of Biochemistry, Albany Medical College, N.Y., for generous provision of ovine and human FSH preparations. The antiandrogen $\mathrm{SCH}-$ 16423 was a gift from Dr Rudolph O. Neri, Schering Corporation, Bloomfield, New Jersey. The work and writing was done while S.G.H. was a Visiting Fellow of the Fogarty International Center, NIH, Bethesda, U.S.A. 


\section{References}

Armstrong, D.T. \& Dorrington, J.H. (1976) Androgens augment FSH-induced progesterone secretion by cultured rat granulosa cells. Endocrinology 99, 1411-1414.

Armstrong, D.T. \& Papkoff, H. (1976) Stimulation of aromatization of exogenous and endogenous androgens in ovaries of hypophysectomized rats in vivo by follicle stimulating hormone. Endocrinology 99, 1 144-1151.

Baird, D.T. \& Fraser, I.J. (1975) Concentrations of oestrone and oestradiol in follicular fluid and ovarian venous blood of women. Clin. Endocr. 4, 259-266.

Boling, J.L., Blandau, R.J., Soderwall, A.L. \& Young, W.C. (1941) Growth of the Graafian follicle and the time of ovulation in the albino rat. Anat. Rec. 79, 313-331.

Channing, C.P. (1970) Influences of the in vivo and in vitro hormonal environment upon luteinization of granulosa cells in tissue culture. Recent Prog. Horm. Res. 26, 589-622.

Channing, C.P. \& Kammerman, S. (1973) Characterization of gonadotropin receptors of porcine granulosa cells during follicle maturation. Endocrinology 92, 531-540.

Channing, C.P. \& Ledwitz-Rigby, F. (1975) Methods for assessing hormone-mediated differentiation of ovarian cells in culture and in short term incubations. Methods Enzymol. 39, 183-230.

Dorrington, J.H., Moon, Y.S. \& Armstrong, D.T. (1975) Estradiol-17 $\beta$ biosynthesis in cultured granulosa cells from hypophysectomized immature rats; stimulation by follicle-stimulating hormone. Endocrinology 97, 1328-1331.

Erickson, G.F. \& Hsueh, A.J.W. (1978) Stimulation of aromatase activity by follicle stimulating hormone in rat granulosa cells in vivo and in vitro. Endocrinology 102, 1275-1282.

Falck, B. (1959) Site of production of oestrogen in rat ovary as studied in micro-transplants. Acta physiol. scand. 47, Suppl. 163, 1-101.

Fortune, J.E. \& Armstrong, D.T. (1977) Androgen production by theca and granulosa isolated from proestrous rat follicles. Endocrinology 100, 13411347.

Goldenberg, R.L., Vaitukaitis, J.L. \& Ross, G.T. (1972) Estrogen and follicle stimulating hormone interactions on follicle growth in rats. Endocrinology 90 , 1492-1498.

Hillier, S.G. \& Ross, G.T. (1979) Effects of exogenous testosterone on ovarian weight, follicular morphology and intraovarian progesterone concentration in estrogen-primed hypophysectomized immature female rats. Biol. Reprod. 20, 261-268.

Hillier, S.G., Knazek, R.A. \& Ross, G.T. (1977) Androgenic stimulation of progesterone production by granulosa cells from preantral ovarian follicles: further in vitro studies using replicate cell cultures. Endocrinology 100, 1539-1549.

Hillier, S.G., Zeleznik, A.J. \& Ross, G.T. (1978) Independence of steroidogenic capacity and luteinizing hormone receptor induction in developing granulosa cells. Endocrinology 102, 937-946.
Hillier, S.G., van den Boogaard, A.J.M., Reichert, L.E., Jr \& van Hall, E.V. (1980) Alterations in granulosa cell aromatase activity accompanying preovulatory follicular development in the rat ovary with evidence that $5 \alpha$-reduced $\mathrm{C}_{19}$ steroids inhibit the aromatase reaction in vitro. J. Endocr. 84, 409-419.

Kolena, J. \& Channing, C.P. (1972) Stimulatory effects of $\mathrm{LH}, \mathrm{FSH}$ and prostaglandins upon cyclic $3^{\prime}, 5^{\prime}-$ AMP levels in porcine granulosa cells. Endocrinology 90, 1543-1550.

Lane, C.E. \& Davis, F.R. (1939) The ovary of the adult rat. I. Changes in growth of the follicle and in volume and mitotic activity of the granulosa and theca during the estrous cycle. Anat. Rec. 73, 429-442.

Lee, C.Y. (1976) The porcine ovarian follicle: III. Development of chorionic gonadotropin receptors associated with increase in adenylyl cyclase activity during follicle maturation. Endocrinology 99, 42-48.

Louvet, J.-P. \& Vaitukaitis, J.L. (1976) Induction of FSH receptors in rat ovaries by estrogen priming. Endocrinology 99, 758-764.

Louvet, J.-P., Harman, S.M. \& Ross, G.T. (1975a) Effects of human chorionic gonadotropin, human interstitial cell stimulating hormone and human follicle-stimulating hormone on ovarian weights in estrogen-primed hypophysectomized immature female rats. Endocrinology 96, 1179-1186.

Louvet, J.-P., Harman, S.M., Schreiber, J.R. \& Ross, G.T. (1975b) Evidence for a role of androgens in follicular maturation. Endocrinology 97, 366-372.

Lucky, A.W., Schreiber, J.R., Hillier, S.G., Schulman, J.D. \& Ross, G.T. (1977) Progesterone production by cultured preantral rat granulosa cells: stimulation by androgens. Endocrinology 100, 128-133.

Makris, A. \& Ryan, K.J. (1975) Progesterone, androstenedione, testosterone, estrone, and estradiol synthesis in hamster ovarian follicle cells. Endocrinology 96, 694-701.

Makris, M. \& Ryan, K.J. (1977) Evidence for interaction between granulosa cells and theca in early progesterone synthesis. Endocr. Res. Commun. 4, 233-246.

Mandl, A.M. \& Zuckerman, S. (1952) Cyclical changes in the number of medium and large follicles in the adult rat ovary. J. Endocr. 8, 341-346.

Marsh, J.M. (1976) The role of cyclic AMP in gonadal steroidogenesis. Biol. Reprod. 14, 30-53.

Mueller, P.L., Schreiber, J.R., Lucky, A.W., Schulman, J.D., Rodbard, D. \& Ross, G.T. (1978) Folliclestimulating hormone stimulates ovarian synthesis of proteoglycans in the estrogen-stimulated hypophysectomized immature female rat. Endocrinology 102, 824-831.

Nimrod, A. \& Lindner, H.R. (1976) A synergistic effect of androgen on the stimulation of progesterone secretion by FSH in cultured rat granulosa cells. Molec. cell. Endocr. 5, 315-320.

Payne, R.W. \& Hellbaum, A.A. (1955) The effect of estrogens on the ovary of the hypophysectomized rat. Endocrinology 57, 193-199.

Pederson, T. (1970) Follicle kinetics in the ovary of the cyclic mouse. Acta endocr., Copenh. 64, 304-323. 
Pencharz, R.I. (1940) Effects of estrogens and androgens alone and in combination with chorionic gonadotropin on the ovary of the hypophysectomized rat. Science, N.Y. 91, 554-555.

Pupkin, M., Bratt, H., Weisz, J., Lloyd, C.W. \& Balogh, K., Jr (1966) Dehydrogenases in the rat ovary. I. A histochemical study of $\Delta^{5}-3 \beta$ - and $20 \alpha$-hydroxysteroid dehydrogenases and enzymes of carbohydrate oxidation during the estrous cycle. Endocrinology 79, 316-327.

Richards, J.S. \& Midgley, A.R., Jr (1976) Protein hormone action: a key to understanding ovarian follicular and luteal cell development. Biol. Reprod. 14, 82-94.

Salomon, Y., Londos, C. \& Rodbell, M. (1974) A highly sensitive adenylate cyclase assay. Analyt. Biochem. 58, 541-548.

Schomberg, D.W., Stouffer, R.L. \& Tyrey, L. (1976) Modulation of progestin secretion in ovarian cells by 17 $\beta$-hydroxy-5 $\alpha$-androstan-3-one (dihydrotestosterone): a direct demonstration in monolayer culture. Biochem. Biophys. Res. Commun. 68, 77-85.

Schreiber, J.R. \& Ross, G.T. (1976) Further characterization of a rat ovarian testosterone receptor with evidence for nuclear translocation. Endocrinology 99 , 590-596.
Smith, B.D. \& Bradbury, J.T. (1963) Ovarian response to gonadotrophins after pretreatment with diethylstilbestrol. Am. J. Physiol. 204, 1023-1027.

Stouffer, R.L., Tyrey, L. \& Schomberg, D.W. (1976) Changes in ${ }^{125}$ I labeled human chorionic gonadotropin binding to porcine granulosa cells during follicle development and cell culture. Endocrinology 99, 516-525.

Williams, P.C. (1940) Effect of stilbestrol on the ovaries of hypophysectomized rats. Nature, Lond. 145, 388-389.

Zachariae, F. (1959) Acid mucopolysaccharides in the female genital system and their role in the mechanism of ovulation. Acta endocr., Copenh. Suppl. 47.

Zeleznik, A.J., Midgley, A.R., Jr \& Reichert, L.E., Jr (1974) Granulosa cell maturation in the rat: increased binding of human chorionic gonadotropin following treatment with follicle-stimulating hormone in vivo. Endocrinology 95, 818-825.

Zeleznik, A.J., Keyes, P.L., Menon, K.M.J., Midgley, A.R., Jr \& Reichert, L.E., Jr (1977) Development-dependent responses of ovarian follicles to FSH and hCG. Am. J. Physiol. 233, 229-234.

Zeleznik, A.J., Hillier, S.G. \& Ross, G.T. (1979) Follicle stimulating hormone induced follicular development: An examination of the role of androgens. Biol. Reprod. 21, 673-681.

Received 5 February 1980 